\title{
Extent of extraneous water and detection of various adulterants in market milk at Mirpurkhas, Pakistan
}

\author{
Ghulam Shabir Barham ${ }^{1 *}$, Muhammad Khaskheli ${ }^{1}$, Aijaz Hussain Soomro ${ }^{2}$ and \\ Zaheer Ahmed Nizamani ${ }^{3}$ \\ ${ }^{1}$ Department of Animal Products Technology, ${ }^{2}$ Institute of Food Sciences and Technology, \\ ${ }^{3}$ Department of Veterinary Pathology, Sindh Agriculture University, Tandojam, PAKISTAN.
}

\begin{abstract}
In Pakistan, milk adulteration is a growing issue of significant importance. This problem persists at every level; from production point to consumption. Adulteration poses ill effects on the public health. This study was designed to screen the various adulterants in the market milk sold in the vicinity of Mirpurkhas district of Sindh, Pakistan during the year 2013. A total of 100 milk samples were collected. Twenty milk samples $(n=20)$ from each of milk producers $(M P)$, milk collectors $(M C)$, middlemen $(M M)$, processors $(P)$ and dairy shops $(D S)$ were examined for various adulterants. Among these adulterants water (73\%) was found in majority of milk samples, followed by detergent (32\%), cane sugar (22\%), caustic soda (20\%), rice flour (17\%), sodium chloride and skimmed milk powder (15\%), hydrogen peroxide (13\%), starch (12\%), formalin (11\%), urea and vegetable oil (10\%), boric acid (8\%), ammonium sulfate (6\%), glucose (5\%), sorbitol (4\%) and arrowroot (1\%), respectively. Freezing point of 65\% milk samples of MP, $75 \%$ of MC, $75 \%$ of MM, $80 \%$ of P and $85 \% \%$ of DS appeared towards $0^{\circ} \mathrm{C}$ rather than that of control milk, and assumed to be adulterated with extraneous water. The averaged extent of water in milk sold by $P$ remarkably higher than that of other milk marketing channels, but statistically non-significant $(P>0.05)$ with all milk intermediaries; $M P, M C, M M$ and $D S$. The risk of adulteration at $D S$ was found to be significantly higher $(P<0.05)$ than $M C$ and $M P$, but not significant $(P>0.05)$ with $P$ and $M M$.
\end{abstract}

Key words: Adulterants, extent of extraneous water, freezing point and market milk.

\section{Introduction}

Milk if present in its natural form has high food value and supplies nutrients like good quality proteins, fat, carbohydrates, vitamins and minerals in significant amount. Besides its general need for human health, milk proteins also provide amino acids which are needed for proper growth of adults and infants [1]. The gross milk production of Pakistan is 49,512 thousand tons, although having good ranking among milk producing countries, milk production and distribution systems are still very traditional and underdeveloped. It is dominated mainly by the informal private sectors, consisting of various agents (i.e. producers, collectors, middlemen, processors, traders, and retailer) each performing a specialized role at a particular point in the supply chain. During summer season, (when milk production is low and the demand is high) adulteration is major problem in the fluid milk supply in Pakistan [2-3]. Milk suppliers increase their margin from the sale of milk through dilution, extraction of valuable component (i.e. cream) and/or addition of bulking additives such as low quality flour to enhance the total solids content. Hence, the milk for consumption has been adulterated to such an extent that there is very little nutritive value left in it [4]. However, the adulteration of milk may pose ill effects on quality of milk, and may cause significant problems for human health. For example, carbonate in milk may produce gastrointestinal problems including gastric ulcer, diarrhea, colon ulcer and electrolytes disturbance. While, the hydrogen peroxide disturbs the antioxidants in the body; distributing the natural immunity hence increasing aging. High level of chloride in the milk disturbs the acid base balance and blood $\mathrm{pH}$ in the body, and the addition of ammonia in the milk may cause regression, loss of acquired immunity, kidney problems and sensory disturbances. Formalin causes vomiting, diarrhea and abdominal pain. It also affects the optic nerves and cause blindness and is one of the potent carcinogens. Boric acid causes nausea, vomiting, diarrhea, kidney damage, acute failure of circulatory system and even death. Benzoic acid produces adverse effects such as asthma, urticaria, metabolic acidosis, and convulsions in sensitive persons. In addition, melamine an industrial chemical causes the urinary tract problems in infants and children [5-13].

\section{Materials And Methods}

\subsection{COLLECTION OF SAMPLES}

An experiment was designed to screen various adulterants in the market milk consumed at the vicinity of Mirpurkhas district of Sindh, Pakistan. A total of 100 unprocessed milk samples were collected and sampling of milk was performed from each of twenty $(n=20)$ milk producers (MP), milk collectors (MC), middlemen 
Extent of extraneous water and detection of various adulterants in market milk at Mirpurkhas,

$(\mathrm{MM})$, processors (P) and dairy shops (DS). All the market milk samples were collected in sterilized labeled screw capped glass bottle, kept in icebox and immediately brought to the Dairy analytical laboratory of the Department of Animal Products Technology, Faculty of Animal Husbandry and Veterinary sciences, Sindh Agriculture University Tandojam, and stored at $4-8^{\circ} \mathrm{C}$ till analysis.

\subsection{SCREENING OF VARIOUS ADULTERANTS}

All the milk samples were screened for the presence of different adulterants through commercially available milk adulteration testing kit and methods as reported by Khaskheli [14-15]. Presence and extent of extraneous water in milk samples was detected by depression of freezing point (through Cryoscope) and calculated by using following formula [16].

$\%$ water added $=$

Freezing point base - observed freezing point

Freezing point base

\section{Statistical Analysis}

The data obtained was subjected to analysis of variance (ANOVA) significant differences of the means were computed using least significant difference (LSD) through computerized statistical package i.e. Student Edition of Statistix (SXW), Version 8.1 (Copyright 2005, Analytical Software, USA).

\section{Result}

\subsection{Detection Of Various Adulterants In Milk Sold By Different Intermediaries}

Market milk samples randomly collected from different milk sale points at vicinity of Mirpurkhas district, viz. milk producers (MP), milk collectors (MC), middlemen (MM), processors (P) and dairy shops (DS), were examined for different adulterants. The water was the most common adulterant $(73 \%)$ found to be in the majority of milk samples, followed by detergent (32\%), cane sugar (22\%), caustic soda (20\%), rice flour (17\%), sodium chloride and skimmed milk powder each (15\%), hydrogen peroxide (13\%), starch (12\%), formalin $(11 \%)$, urea and vegetable oil each $(10 \%)$, boric acid $(8 \%)$, ammonium sulfate $(6 \%)$, glucose $(5 \%)$, sorbitol $(4 \%)$ and arrowroot $(1 \%)$, salicylic acid and hypochlorite each $(0 \%)$ from a total of 100 samples (Figure-1).

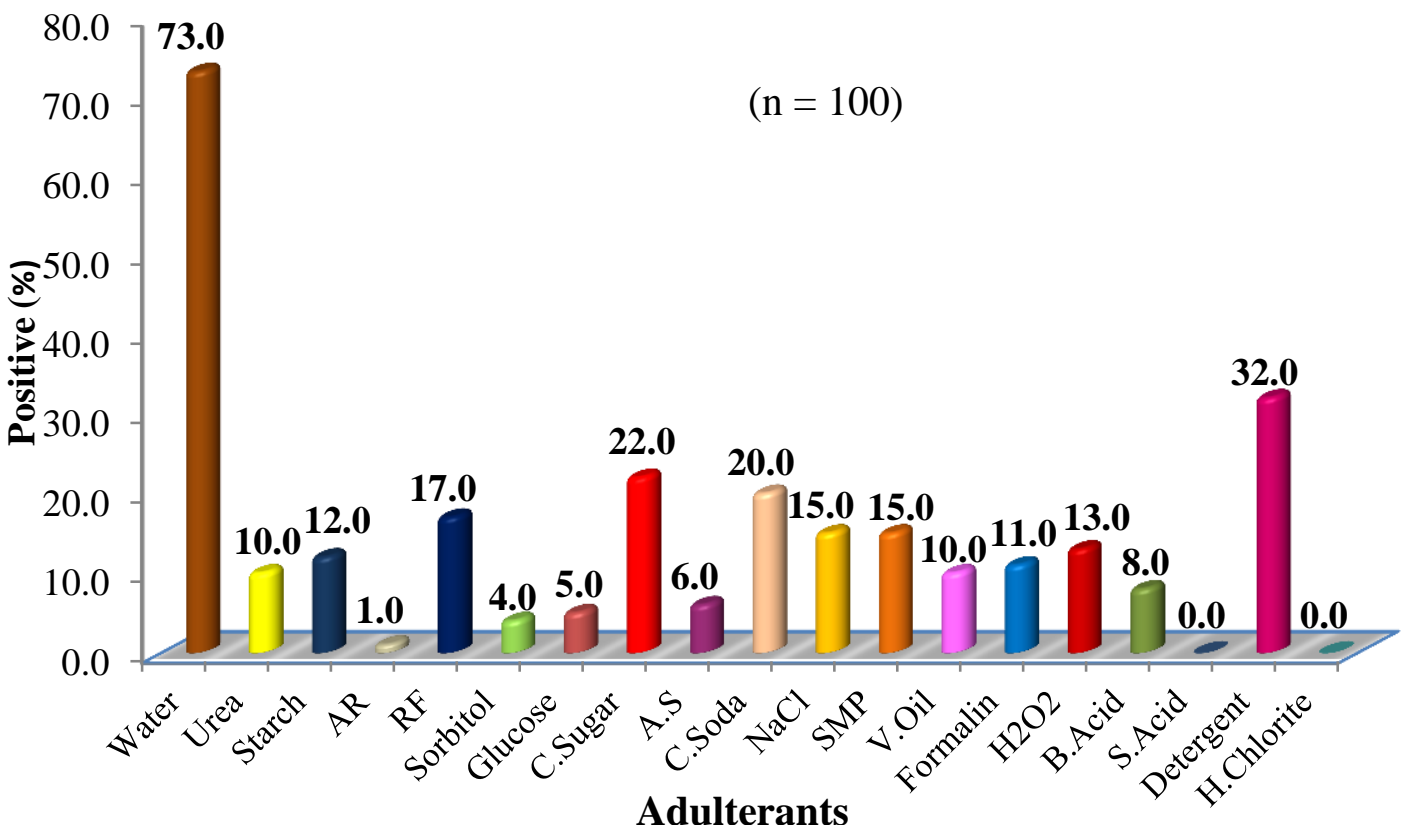

Legends: $\quad A R=$ Arrowroot, $\mathrm{RF}=$ Rice flour, $\mathrm{AS}=$ Amonium sulfate, C.Sugar $=$ Cane sugar, C.Soda $=$ Caustic soda, $\mathrm{NaCl}=$ Sodium chloride, $\mathrm{SMP}=$ Skimmed milk powder, V.Oil = Vegetable oil, $\mathrm{H} 2 \mathrm{O} 2=$ Hydrogen peroxide, $\mathrm{B}$. Acid $=$ Boric acid, S.Acid $=$ Salicylic acid, H.Chorite $=$ Hypochlorite

Figure:1 Positive percent of various adulterants detected in market milk samples of Mirpurkhas, Pakistan. 
Extent of extraneous water and detection of various adulterants in market milk at Mirpurkhas,

\subsection{FREEZING POINT OF MILK SOLD AT DIFFERENT INTERMEDIARIES}

The freezing point of control milk ranged between -0.561 to $-0.522^{\circ} \mathrm{C}$ and averaged as $-0.540 \pm 0.003$ ${ }^{\circ} \mathrm{C}$. While in case of milk sold by MP, the average freezing point varied between -0.534 to -0.441 and averaged $0.332 \pm 0.07$. Further, the freezing point of milk from MC was in a range between -0.561 and $-0.195^{\circ} \mathrm{C}$ with an average of $-0.340 \pm 0.03{ }^{\circ} \mathrm{C}$, and it varied between -0.531 and -0.187 with mean of $-0.421 \pm 0.02{ }^{\circ} \mathrm{C}$ in milk of $\mathrm{MM}$ and in between -0.553 and $-0.226{ }^{\circ} \mathrm{C}$ with an average of $-0.415 \pm 0.02{ }^{\circ} \mathrm{C}$ in milk of P. However, the freezing point of milk sold at DS varied between -0.538 to $-0.197^{\circ} \mathrm{C}$ and averaged $-0.383 \pm 0.2{ }^{\circ} \mathrm{C}$. The least significant difference (LSD, 0.05) of mean test revealed no significant difference $(\mathrm{P}>0.05)$ in average freezing point of milk sold by MP, MC, MM, $\mathrm{P}$ and DS, while control milk varied considerably $(\mathrm{P}<0.05)$ in average freezing point from the milk of all intermediaries (Table-1).

Table: 1 Freezing point of market milk sold by different intermediaries at Mirpurkhas.

\begin{tabular}{|c|c|c|c|c|c|c|c|c|}
\hline \multirow[b]{2}{*}{$\begin{array}{l}\text { Descriptive } \\
\text { measures }\end{array}$} & \multicolumn{6}{|c|}{ Freezing point of milk $\left({ }^{\circ} \mathrm{C}\right)$} & \multicolumn{2}{|c|}{ Significance } \\
\hline & Control & $\begin{array}{l}\text { Milk } \\
\text { Producers }\end{array}$ & \begin{tabular}{|l} 
Milk \\
Collectors
\end{tabular} & Middlemen & Processors & $\begin{array}{l}\text { Dairy } \\
\text { Shops }\end{array}$ & P-value & $\begin{array}{l}\text { LSD } \\
(\mathbf{0 . 0 5}) \\
\pm \mathrm{SE}\end{array}$ \\
\hline Minimum & -0.561 & -0.534 & -0.561 & -0.531 & -0.553 & -0.538 & \multirow{4}{*}{$<0.001$} & \multirow{4}{*}{$\begin{array}{c}0.0964 \\
\pm \\
0.0487\end{array}$} \\
\hline Maximum & -0.522 & -0.441 & -0.195 & -0.187 & -0.226 & -0.197 & & \\
\hline Mean* & $-0.540^{\mathrm{b}}$ & $-0.332^{\mathrm{a}}$ & $-0.340^{\mathrm{a}}$ & $-0.421^{\mathrm{a}}$ & $-0.415^{\mathrm{a}}$ & $-0.383^{\mathrm{a}}$ & & \\
\hline $\mathrm{SE} \pm$ & 0.0027 & 0.07 & 0.03 & 0.02 & 0.02 & 0.02 & & \\
\hline
\end{tabular}

*Means with different letters in same row varied significantly from one another.

Moreover, $65 \%$ milk samples of MP, $75 \%$ of MC, $75 \%$ of MM, $80 \%$ of $\mathrm{P}$ and $85 \%$ of milk sold at DS did not show the similarity with freezing point of control milk $\left(-0.522\right.$ to $\left.0.651^{\circ} \mathrm{C}\right)$ and assumed to be positive, adulterated with extraneous water, while $35,25,25,20$ and $15 \%$ samples were in range of freezing point of control milk samples and assumed to be negative, respectively (Figure-2).

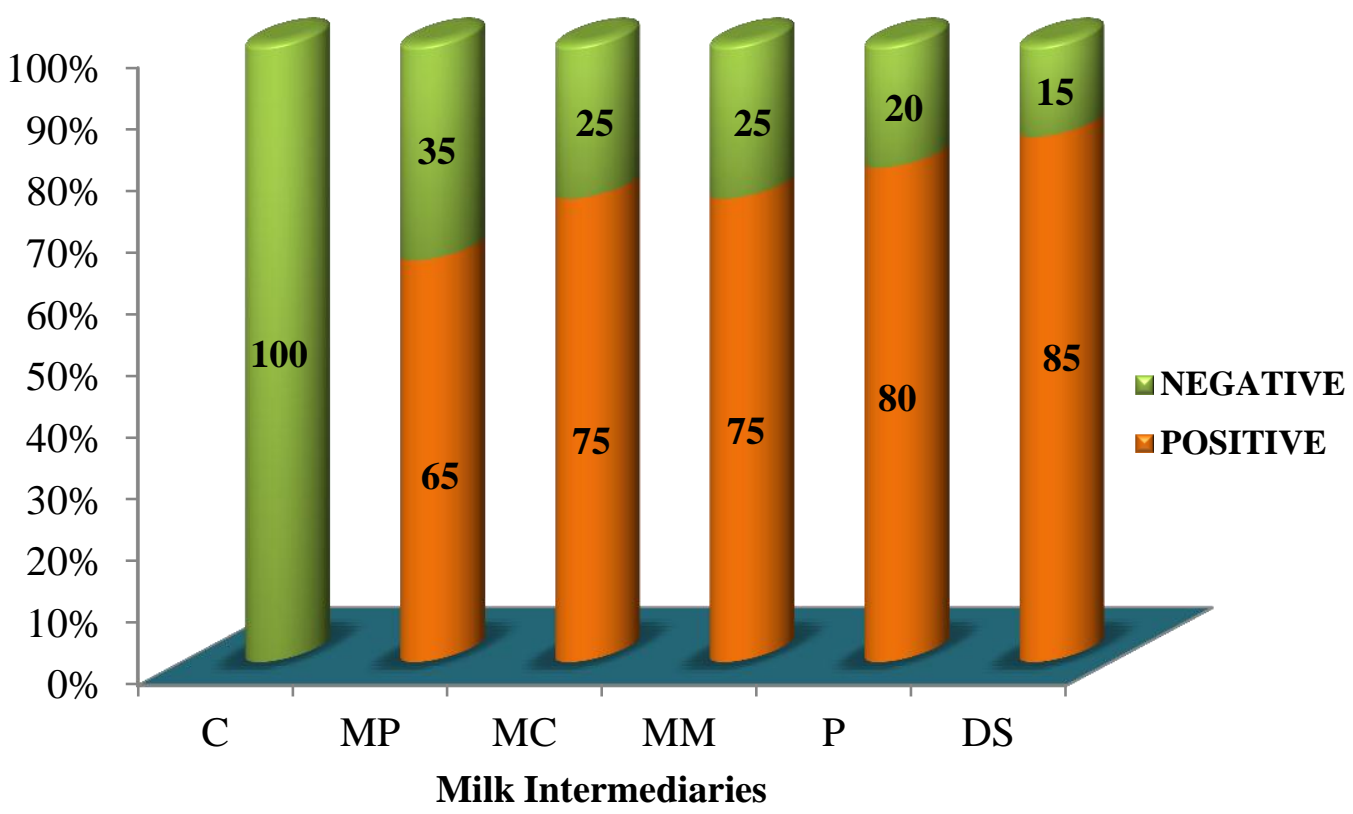

Legends: $\quad \mathrm{C}=$ Control, $\mathrm{MP}=$ Milk producers, $\mathrm{MC}=$ Milk collectors, $\mathrm{MM}=$ Middlemen, $\mathrm{P}=$ Processors and DS = Dairy shops.

*Milk samples with freezing point below the range of control milk $\left(-0.522\right.$ to $\left.-0.561^{0} \mathrm{C}\right)$

Figure: 2 Market milk samples (\%) varied in freezing point from control milk collected from different intermediaries at Mirpurkhas, Pakistan. 


\subsection{Extent Of Extraneous Water In Milk Sold By Different Intermediaries}

Extent of extraneous water of milk sold by different milk marketing channels was detected from the depression of freezing point. The average water percent in milk of P $(27.9 \pm 4.4 \%)$ followed by milk of MC (26.1 $\pm 4.9 \%)$, DS $(23.3 \pm 3.9 \%)$ MM was $(22.0 \pm 3.9 \%)$ and MP (17.94 $\pm 3.7 \%)$. Statistical analysis (LSD, 0.05) showed no significant differences ( $\mathrm{P}>0.05$ ) among all milk intermediaries; MP, MC, MM, P and DS (Figure-3).

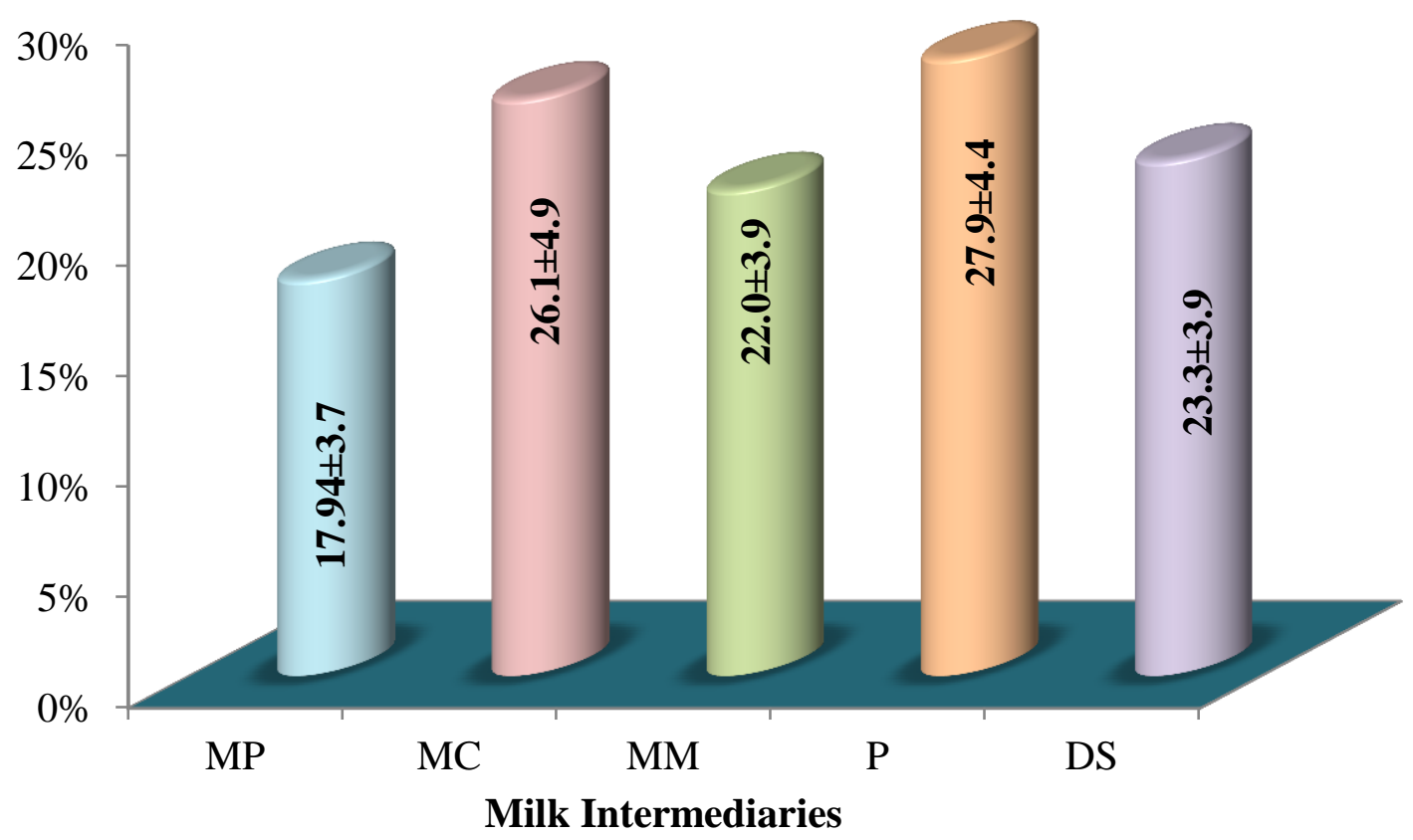

Legends: $\quad \mathrm{MP}=$ Milk producers, $\mathrm{MC}=$ Milk collectors, $\mathrm{MM}=$ Middlemen, $\mathrm{P}=$ Processors, $\quad$ DS $=$ Dairy shops.

$\begin{array}{lll}\operatorname{LSD}(0.05) & = & 11.878 \\ \mathrm{SE}+ & = & 5.983\end{array}$

Figure: 3 Extent of extraneous water in market milk sold by different intermediaries at Mirpurkhas, Pakistan.

\subsection{Extent Of Adulteration In Milk Sold By Different Intermediaries}

The extent of adulteration in milk sold by different milk marketing channels was calculated and it was noted that $4.21 \%$ adulteration done at DS, followed by MC (3.53\%), MM (3.16\%), P (2.47\%) and MP (1.05\%), respectively. Statistical analysis (ANOVA) showed that the extent of adulteration at DS, MM, MC and P was statistically non-significant $(\mathrm{P}>0.05)$ with each other, but ratio of adulteration at DS and MC was significantly higher $(\mathrm{P}<0.05)$ than that of MP $($ Figure-4). 


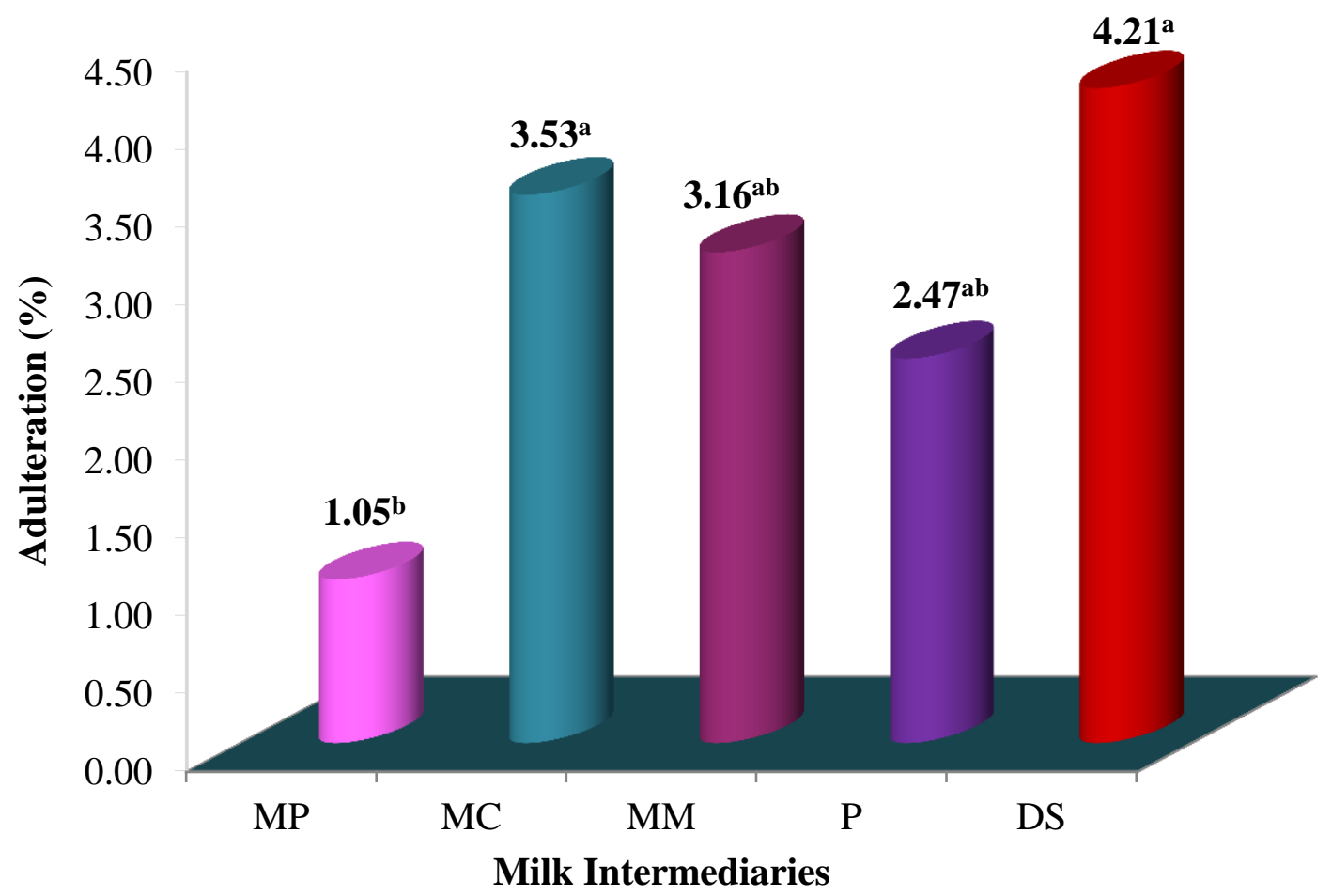

Legends: $\quad \mathrm{MP}=$ Milk producers, $\mathrm{MC}=$ Milk collectors, $\mathrm{MM}=$ Middlemen, $\mathrm{P}=$ Processors

$\operatorname{LSD}(0.05) \quad=\quad$ DS = Dairy shops

$\mathrm{SE} \pm \quad \quad \quad \quad 1.091$

\section{Figure:4 Extent of adulteration in market milk sold by different intermediaries at Mirpurkhas, Pakistan.}

\section{Discussion}

Milk adulteration, poor hygiene, lack of preservation technology, cooling facilities and sanitation conditions are the main causes of losses in quality of milk [5]. The milk supply is reduced in summer due to fall $(55 \%)$ in milk production and increase in demand $(60 \%)$ compared to winter when milk supply is ample. To cope with demand, water is admixed with whole milk to increase the volume of milk during summer season. It has been reported that milk adulteration is common in developing countries and that has direct influence on the quality characteristics of milk

The water was common adulterant found to be in majority of milk samples (73\%) evaluated in present study. Similarly, it was reported that the water is the main adulterant which was frequently used for adulteration of milk in various countries of the world [17-20]. It has been noticed that addition of water to normal whole milk was assumed to increase the quantity of milk. Gawalas/dhodis tend to mix muddy water rather than clean tap water in order to increase density and keep milk thick, it is not only reduces the nutritional value of milk but contaminated water may also pose a health risk ([21-22] ). The proportion of samples adulterated with various adulterants varied in different studies. When water is added in milk, its foamy appearance diminishes, so to give milk a foamy appearance and to enhance its cosmetic nature artificially detergents are added [23-24]. Milk samples collected from various canteens of Faisalabad city hospitals were found to be positive with water, cane sugar, urea, formalin and starch [4]. It is of interest to note that the middlemen attempt to counter the dilution by adding cane sugar to extend the solids content of the milk or as additives for the purpose of masking the effect of dilution of water. $12 \%$ in summer, $10 \%$ in rainy and $2 \%$ in winter season milk samples were found to be adulterated with formaldehyde, sodium chloride with starch. Wheat flour, arrowroot and rice flour and starch are mostly added for increasing the solids not fat (SNF) content and viscosity of milk up to an accepted level of consumers. Caustic soda, sodium 
Extent of extraneous water and detection of various adulterants in market milk at Mirpurkhas,

carbonate and bicarbonate are also frequently used to neutralize the $\mathrm{pH}$ and acidity of milk by the milk traders in Pakistan. [25-29]. However, high amount of starch may cause diarrhea due to the effects of undigested starch in colon, and its accumulation in the body may pose a danger for diabetic patients [7]. In another study the milk samples were found contaminated with formaldehyde. The formalin is used as preservative of milk for increasing the shelf life but it not only decreases the nutritive value of milk but also is carcinogenic [21] and [29-30]. In the present study sodium chloride was found in 19\% milk samples among total 100 milk samples examined. Similar adulterant was used for adulteration in Assam state of India and Brazil. Sodium chloride was added in milk to mask the high water content [31]. It has been reported that high level of sodium chloride in milk could affect the acid base balance in body and may develop regression loss of acquired immunity, kidney problems, speech and sensory disturbances [8]. Further, the findings of present study regarding milk samples adulterated with skimmed milk powder, glucose, ammonium sulfate hydrogen peroxide, formalin, boric acid, benzoic and salicylic acid are also supported by the findings of various researchers. They reported that milk samples were found positive for skimmed milk powder and glucose, which were used to increase the TS content of milk. Ammonium sulfate was used as an additive for the purpose of masking the effects of dilution of water in the milk. Hydrogen peroxide, formalin, benzoic acid, boric acid, benzoic and salicylic acid are used as chemical preservatives for milk. These are usually used to increase the shelf life of milk during summer season when environmental temperature is very high. This unethical activity is usually adopted by the milk traders to prevent the financial losses due to the spoilage of milk during its transportation and sale in various parts of the world [32-35]. In Pakistan and China, vegetable oil was added in milk by removing the true fat and cream from it to maintain the fat ratio by milk traders [36-37]. In India, $27 \%$ milk samples in winter and $12 \%$ in summer and $10 \%$ in rainy season were found to be adulterated with carbonates/bicarbonates [38].

The freezing point of milk samples collected from different intermediaries was significantly $(\mathrm{P}<0.05)$ varied from control milk samples. Addition of extraneous water in milk will have adverse effect on freezing point and nutritional quality. In the present study the mean extent of extraneous water found to be comparatively higher $(\mathrm{P}<0.05)$ in milk sold at DS, MC, $\mathrm{P}$ and MM than that of milk sold by MP. Similarly, average extent of extraneous water was found to be higher in market milk samples and the ratio of adulteration in milk was high in urban areas as compared to the rural areas. The percentage of extraneous water was found to be higher in milk samples collected from milk vendors than dairy farms [39-41]. For the fulfillment of the gap between demand and supply different milk marketing dealers adulterated the milk by adding water which is probably carried out during the handling of milk starting from milking till it reaches the consumer or end user. Milk dealers also add dirty ice to increase the shelf life of milk which is also one of the reasons of elevated level of extraneous water in milk samples. In Pakistan raw milk is distributed by a traditional system which involves middlemen called Gawalas. These milk dealers; middlemen and dairy shop keepers adulterate milk to maximize their profit. [3] and [36-38]. Therefore, it was observed that the percentage of adulteration at dairy shop (DS), milk collectors and middlemen was significantly $(\mathrm{P}<0.05)$ higher than that of processors and milk producers, respectively.

\section{Conclusions}

Accumulating evidence has shown that, on the basis of freezing point temperature of control milk majority of milk samples from different intermediaries were found adulterated with extraneous water. The water was the most common adulterant found in majority of market milk samples followed by detergent, cane sugar, starch, rice flour, formalin, sodium chloride, skimmed milk powder, urea, hydrogen peroxide, ammonium sulfate, vegetable oil, boric acid, caustic soda, glucose, arrowroot, hypochlorite, salicylic acid and sorbitol sold at the vicinity of Hyderabad district of Sindh, Pakistan. The extent of extraneous water and risk of adulteration at dairy shops (DS), milk collectors $(\mathrm{MC})$ and middlemen $(\mathrm{MM})$ was significantly $(\mathrm{P}<0.05)$ found to be higher as compared to processors (P) and milk producers (MP).

\section{Acknowledgement}

We are very grateful to Higher Education Commission (HEC), Islamabad, Pakistan for awarding me Indigenous $5000 \mathrm{PhD}$ fellowship. This portion of $\mathrm{PhD}$ research work on 'Detection and extent of extraneous water and adulteration in milk consumed at Hyderabad, Pakistañ is fully supported by Higher Education Commission (HEC) Islamabad, Pakistan.

\section{References}

[1] Neumann, C.G., D.M. Harris and L.M. Rogers. Contribution of animal source foods in improving diet quality and function in children in the developing world. Nutrition Research, (22), 2002, 193-220.

[2] Farooq, O. Agriculture. In: Pakistan economic survey, 2012-2013. Economic Advisers Wing, Finance Division, Government of Pakistan, Islamabad.

[3] Zia, U. (2006). Analysis of milk marketing chain, Pakistan. FAO. Food Laws Manual. 2006.

[4] Lateef, M., A. Faraz, M.I. Mustafa, P. Akhtar, and M.K. Bashir. Detection of adulterants and chemical composition of milk supplied to canteens of various hospitals in Faisalabad city. Pakistan Journal of Nutrition, (9), 2009, 139-142. 
[5] Haasnoot, W., N.G. Smits, A.E.K. Voncken and M.G. Bremer. Fast biosensor immunoassays for the detection of cows' milk in the milk of ewes and goats. Journal of Dairy Research, 71, 2004, 322-329.

[6] Beall, D.P, and R.H. Scofield, Milk-alkali syndrome associated with Calcium carbonate consumption. Reports of seven patients with parathyroid hormone levels and an estimate of prevalence among patients hospitalized with hypocalcaemia. Medicine. 74 (2), 1995, 89-96.

[7] Rideout, T.C., Q. Liu, P. Wood and M.Z. Fan. Nutrient utilization and intestinal fermentation are differentially affected by the consumption of resistant starch varieties and conventional fibers in pigs. British Journal of Nutrition, (99), 2008 984-92.

[8] Ayub, M., Q. Ahmed, M. Abbas, I.M. Qazi and I.A. Hattak. Composition and adulteration analysis of milk samples. Sarhad Journal of Agriculture, 23 (4), 2007, 1127-1130.

[9] Gwin, M.C., G. Lienert and J. Kennedy. Formaldehyde exposure and asthma in children. A systematic review. Environment Health Perspective, 118, 2009, 313-317.

[10] See, A.S., A.B. Salleh, F.A. Bakar, N.A. Yusof, A.S. Abdulamir and L.Y. Heng Risk and health effect of boric acid. American Journal of Applied Sciences, 7, 2010, 620-627.

[11] Mota, F.J.M, F. Implvo, S.C. Cunha, M. Beatriz and P.P. Oliveira. Optimization of extraction procedures for analysis of benzoic and sorbic acids in foodstuffs. Food Chemistry 3 (82), 2003, 469-473.

[12] Saad, B., M.F. Bari, M.I. Saleh, K. Ahmad and M.K.M. Talib. Simultaneous determination of preservatives in food stuffs using HPLC. Journal of Chromatography Analysis, (1073), 2005, 393.

[13] Li, Z., L.L. Wu, Y.P. Wang, A.M Liu, C.C Zou, and Z.Y. Zhao. Melamine contaminated milk products induced urinary tract calculi in children. World Journal of Pediatrics, 5 (1), 2009, 31-35.

[14] Tipu, M.Y., I. Altaf, M. Ashfaq, and S. Siddiqui. Introduction. In Proceedings of the workshop on monitoring of chemical adulterants and hygienic status of market milk. Lahore, Pakistan: (WTO-Quality Control Laboratory, 2007), 7-39.

[15] Khaskheli, M. Dairy Laboratory Manual. (Department Animal Products Technology, Faculty Animal Husbandry and Veterinary Sciences, Sindh Agriculture University, Tandojam, 2010), 38

[16] AOAC, Official methods of analysis of the association of official analytical chemists. (Inc. Gaithersburg, U.S.A., 2000)

[17] Butt, M.Y.M. (2011). Seminar on Milk Anti-adulteration policy Policy Draft: International executive summary dairy report, (IFCN) Pak. Lahore.

PSQCA, 2006. Formalin in Nestle Pakistan milk. Network for consumer report. (Release No 0017/06)

Beniwal, A., Khetarpaul, N. (1999). Knowledge of consumers regarding the nature and extent extent of adulteration of Indian foods. Nutrition Health, 13 (3):153-60.

Ahmed, A.A.H. Milk adulteration by adding water and starch at Khartoum state, Pakistan Journal of Nutrition, 8 (4), 2009, 439443.

[21] Bhatti, M.Y. (2010). Formalin in milk consultancy report of Lahore High court. Free News alerts sums' PT to 9900

[22] Pitty, (2011). 69 PC milk samples fail quality test some contain detergents. A national survey on milk adulteration. Conducted by Food Safety and Standards Authority of India. reported by PTI.

[23] Walker, G.P., Dunshea, F.R. \& Doyle, P.T. (2004). Effects of nutrition and management on the production and composition of milk fat and protein. Australian Journal of Agriculture Research. (55): 1009-1028.

[24] Manish, M.P., Singhal, R.S. \& Kulkarni, P.R. (2000). An approach to the detection of synthetic milk in dairy milk, 1. Detection of urea. International Journal of Dairy Technology, 53. (3): 987-91.

[25] Fakhar, H. \& Law Walker, F.G. (2006). The white revolution-dhoodh darya. Pakistan Dairy Development Company, (pp. 72).

[26] Singhal, R.S., Kulkarni, P.R. \& Rege, D.V. (1997). Handbook of Indices of food quality and authenticity. Wood Head Publishing Limited, Cambridge England, (pp.168-174).

[27] Wadekar, S. B. \& Menkudale, G.V. (2011). Physico-chemical quality of market milk in Nanded town. Vision Research Review. I (I): (pp.27).

[28] Tariq, M.A., 2001. Subject: A close look at dietary patterns http://www.dawn.com/2001/11/05/ebr13. Htm. Accessed Feb, 2011.

[29] Afzal, A., Mahmood, M.S., Hussain, I. \& Akhtar, M. Adulteration and microbiological quality of milk. Pakistan Journal of Nutrition, 10 (12), 2011. 1195-1202.

[30] Ibtisam, E., El- Zubeir, M., El- Owni, O.-A.-O. (2009). Antimicrobial resistance of bacteria associated with raw milk contaminated by chemical preservatives. World Journal of Dairy and Food Science, 4 (1): 65-69.

[31] Fertig, C.C., Podczeck, F., Jee, R.D. \& Smith, M.R. (2004). European Journal of Pharmacology Science, 2,155

[32] Sinha, K. (2012). 70\% of milk in Delhi, country is adulterated consultancy Report http://timesofindia.indiatimes.com/topic/FoodSafety-Standards-Authority- of- India.

[33] Goswami, T.K., \& Gupta, S.K. (2008). Detection of dilution of milk with the help of glass transition temperature by differential scanning calorimetry (DSC). African Journal of Food Science, 2, 7-10.

[34] Naz, W. (2000). Subject: The dairy sector. http://www. Pakistaneconomist.com. Accessed Feb. 2011.

[35] Yildiz, A., Erdogan, S., Saydut, A. \& Hamamci, C. (2012). High-Performance Liquid Chromatography analysis and assessment of benzoic acid in yogurt, ayran, and cheese in Turkey. Food Analytical Methods. (5): 591-595.

[36] Zia, U. (2007). Improved market access and smallholder dairy farmer participation for sustainable dairy development. Consultancy Report CFC/FIGMDP/ 16FT. Lessons Learned Study. Islamabad, Pakistan.

[37] Gale, F., \& Hu, D. (2007). Supply chain issues in China's milk adulteration incident. Economic Research Service U. S. Department of Agriculture Washington, DC.

[38] Sanjeevani, B.W., Chavan, B.R. \& Menkudale, G.V. (2011). Survey on adulteration of the milk received from Government milk scheme in banded town. Journal of International link Research Analysis, 1 (4): 32-35.

[39] Nida, S., Soomro, A.H. Sheikh, S.A. \& Khaskheli, M. (2013). Extent of water adulteration and its influence on physical characteristics of market milk. Pakistan Journal of Nutrition, 12 (2): 178-181.

[40] Meredith, P., Williams, P., Zampa, N., Garry, E. \& Ouattara, G. (2007). The effect of raw milk storage conditions on freezing point, $\mathrm{pH}$ and impedance. Advance Instruments, INC., (pp: 1-7).

[41] Bhatt, S.R., Singh, A. \& Bhatt, S.M. (2008). Assessment of synthetic milk exposure to children of selected population in Uttar Pradesh, India. Indian Journal of Research, 7: 22-34. 